\title{
AUGMENTED REALITY IN ARCHITECTURE: REBUILDING ARCHEOLOGICAL HERITAGE
}

\author{
J. de la Fuente Prieto ${ }^{a *}$, E. Castaño Perea ${ }^{\mathrm{b}}$ and F. Labrador Arroyo ${ }^{\mathrm{c}}$ \\ ${ }^{a}$ Dept. de Filología, Comunicación y Documentación. Universidad de Alcalá, C/ Trinidad, 5 \\ 28801 Alcalá de Henares, Madrid, Spain - julian.fuente@uah.es

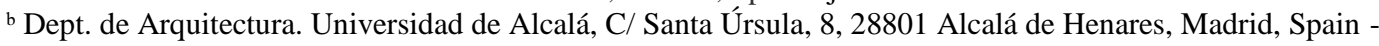 \\ enrique.castano@uah.es \\ c Dpto. CC. de la Educación, el Lenguaje, la Cultura y las Artes, CC. Histórico-Jurídicas y Humanísticas y Lenguas Modernas. \\ Universidad Rey Juan Carlos, Paseo de los Artilleros s/n 28320 Madrid, Spain -felix.labrador@urjc.es
}

Commission II

KEY-WORDS: Augmented Reality, Architectural Representation, Archaeological Reconstruction, Cultural Heritage

\begin{abstract}
:
With the development in recent years of augmented reality and the appearance of new mobile terminals and storage bases on-line, we find the possibility of using a powerful tool for transmitting architecture. This paper analyzes the relationship between Augmented Reality and Architecture. Firstly, connects the theoretical framework of both disciplines through the Representation concept. Secondly, describes the milestones and possibilities of Augmented Reality in the particular field of archaeological reconstruction. And lastly, once recognized the technology developed, we face the same analysis from a critical point of view, assessing their suitability to the discipline that concerns us is the architecture and within archeology.
\end{abstract}

\section{INTRODUCTION}

With the development in recent years of augmented reality and the appearance of new mobile terminals and storage bases on-line, we find the possibility of using a powerful tool for transmitting architecture. The technology is developing at high speed so it's time to make a critical reflection both from the technical point of view its use and reliability, and from their critical and professional validity approach.

\subsection{Virtual Reality to Augmented Reality}

Computer technology has facilitated the generation of 3D images from the beginning of the first graphic interfaces. In fact, this computing power has allowed the creation of complex 3D visual environments for all kinds of applications such as video games, geographic information systems, as well as graphic, industrial and architectural design. However, these 3D Images have always needed a computer interface to be represented. No matter about how realistic it was playing these 3D objects, always they remitted us to a Virtual Reality.

The first who was try to overcome this antithetical opposition between the "real" world and "virtual" were Milgram and Kishino (1994) by making its Continuous Real-Virtual's model. His proposal was trying to integrate real and virtual elements in a Mixed Reality that could be experienced in continuity with both worlds.

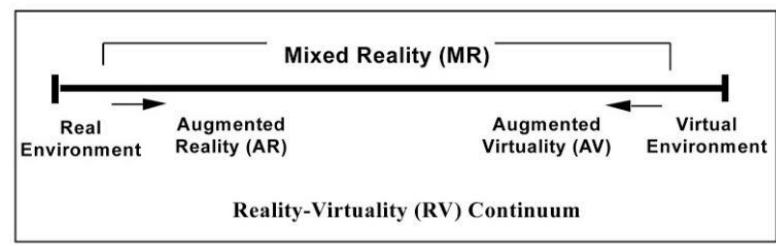

Figure 1. "Continuo Real-Virtual” en Milgran y Kishino (1994).

Through this paradigm, in the mid-90s began to develop a new technology derived from real-world application of this Virtual Reality; characterized by inserting objects or virtual space in a real scenario (Ruiz Torres, 2011a: 3) It is what is now knowing as Augmented Reality and allows us to visualize 3D elements through any type of device reproducing a real image.

This condition could be attributed to any type of assembly or photo correcting, but according Fernández Álvarez the key to this Augmented Reality is that there is a true correspondence between the real and the virtual in terms of scale, proportion, proximity, perspective, depth, etc., which allows the user in some applications experience space full scale. (2010: 3) Therefore, we are proposing a paradigm that is not intended to recreate a new virtual world, but to create a single integrated both real space and 3D images by visual world.

\footnotetext{
* Corresponding author
} 


\section{¿VEN A LA UNIVERSIDAD AUMENTADA!}

\author{
पกी
}

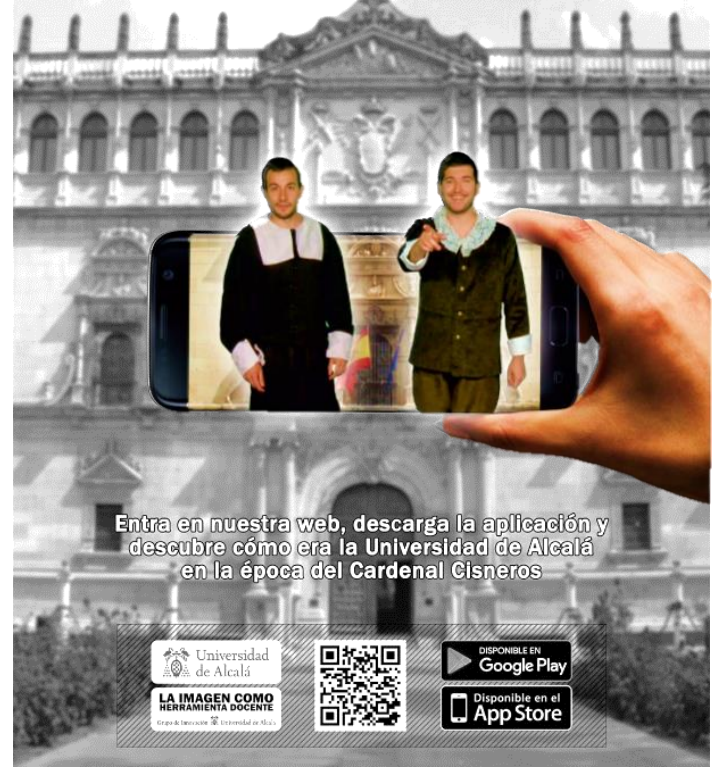

Figure 2. Announcement poster of the application. "universidadaumentada.com". UAH

\section{AUGMENTED REALITY AND ARCHAEOLOGICAL RECONSTRUCTION}

Augmented Reality and Architecture are areas of research that converge inevitably; especially in the field of archeology. Archaeology has always needed tools to interpret and disseminate the remains found in any field, while Augmented Reality is born with the desire to enrich and expand our ability to visualize the real world.

Now we reflect on these existing technologies and their ability to go together into archeology and architecture with the quality to be useful for both professionals and amateurs.

\subsection{The Cultural Heritage and archaeological reconstruction.}

Although the legislation is decentralized for Cultural Heritage in each Autonomous Community, the law 13/1985 of Spanish Historical Heritage remains the legal document that inspires any work on an archaeological site. Its tasks makes it clear that conservation, consolidation and rehabilitation of archaeological heritage will prevent attempts at reconstruction except when original parts thereof are used and can prove its authenticity. This principle has set the trend for the so-called "fossilization" of deposits, preserving the appearance of archaeological remains after excavation surface.

However, the same law heritage in its preamble states that all measures to protect and promote the Act provides only make sense if, in the end, lead to an increasing number of citizens can see and enjoy the works they are the legacy of the collective capacity of a people. In the case of archaeological heritage, it is difficult for citizens to contemplate and enjoy archaeological remains can hardly get to play. So many archaeologists claim as Joan Santacana long; promote the use of reconstruction as an educational tool in the treatment of the archaeological heritage. (Gil and Santacana, 2013)

In the countries of northern Europe legislation it is always more likely to practice in reconstructive archaeological sites. However, its application holds numerous problems in preserving the contributions of different historical periods on the same site, or just time to rethink scientifically forms or uses of the reconstructed structures. Finally, we must not forget that the public can easily fall into the error of considering the materials reconstituted as original and therefore introduce the tendency to value the archaeological remains according to their degree of conservation or reconstruction. None of this would be a problem if the archaeological reconstruction could raise multiple, reversible and interactive with the public way.

\subsection{Augmented Reality and Virtual Archeology.}

Since its inception, all experts agreed that this paradigm of interaction and information visualization is the center of a new and very promising technology for many applications in many sectors (Alonso, Balaguer et al, 2001: 3) However there he noted that so far the first tests with Augmented Reality have been linked to the world of archeology showing the advantages and potential that has applied to the heritage field (Ruiz Torres, 2011a: 3) This is no coincidence if we note that these resources are able to create inspired by the basic principles of heritage interpretation experience: participatory tools that provoke curiosity and stimulate the senses through participation in simple applications, facilitating the assimilation of the main theme, inviting him to deepen the content or encouraging him to repeat on another occasion the visit. (Flores Gutiérrez, 2011: 1)

Without being too exhaustive, we can select some of the most prominent examples of use of Augmented Reality to spread the archaeological heritage according Gómez García Robles and Quirosa (2009):

- $\quad$ 1997: "TIMEFRAME" Augmented Reality Viewer with high resolution located in the Belgian city of Ename.

2000: "ARCHEOGUIDE"; first Augmented Reality application for several monuments of Olympia in Greece.

2001: "Vilars"; first Augmented Reality application developed in Spain at the site of Arbeca in Lleida.

2002: "LIVEPLUS"; full implementation of Augmented Reality covering the site of Pompeii in Italy.

All these projects have in common a long development process as we have seen, involves first the design of 3D objects themselves who want to bring the Augmented Reality. These jobs generally require multidisciplinary cooperation of specialists in Virtual Reality, archaeologists, historians or writers (Gutierrez and Hernandez, 2003: 10) So the first problem is to establish a series of guidelines that should mark the completion scientific criteria these virtual images; which have a major impact on the convictions of the public who succumbs to the power of visual images (Gómez García Robles and Quirosa 2009: 6)

However, we found differences in the different uses to which the Augmented Reality in each of these examples is applied. Following the speech of several authors we can summarize three approaches when using Augmented Reality to publicize the archeological heritage:

- Reconstruction of dilapidated buildings or significantly altered. 
- Recreation archaeological missing or damaged parts.

- Simulation of social or natural environments on archaeological sites.

These informative functions, we must add other approaches that consider also useful in scientific contexts generating 3D images to simulate and investigate certain intangible material objects according to Gutierrez and Hernandez (2003):

- Rehearse restoration techniques on synthetic models.

- Specular with different assumptions about lost objects.

- Analyze an archeological object in its original environment.

Therefore, it is necessary to propose new ways of content associated to this technology that go beyond the simple virtual reconstruction of historical buildings. Through virtual reality it must be possible to enjoy new experiences that couldn't happen in the real world, even where it has already disappeared, and help you better understand what the heritage means beyond their spatial analysis. Regarding this, Gutierrez and Hernandez defend also:

Incorporating multimedia, multi-exploration, the telepresence and the ability to display worlds in ways that are not subject to the physical limitations of the world we live take this technology to become no longer an emulation of what exists, but an expansion of our own reality. (Gutierrez and Hernandez 2003: 14)

This coincides perfectly with the aim of Augmented Reality that according to Fernandez Alvarez is simply to overcome the difficulties of understanding due to different levels of conceptual abstraction presenting different traditional representation systems (2010: 4)

The process for carrying out the reconstruction of a reservoir through Augmented Reality makes sense only if it is preceded by a scientific work. Archaeological research is what should determine both the design and the location of virtual elements who integrate into the current state of the site.

The next step to carry out the integration of 3D objects in the real world, is to establish the scale on which should generate these virtual elements. Whether it is isolated parts partially preserved as a surface area; It's necessary to carry out a measurement of the real through photogrammetric techniques (Blasco Senabre, 2011) space. From the intersection of photographs or digital terrain model, we can know the dimensions and position of real objects in space and determine the proportion of integrating virtual elements.

Then it will take place the process of creating 3D object through some of the different applications that exist in the market and allow the following steps:

- Modeling: form is given to the figure by geometric objects.

- Set-up: joints or different possible states are created.

- Texture and color: a coating with detail and color are generated.

- Lighting: effects of light on the object are applied to enhance its three-dimensional perspective.

- Render: a final image is obtained in compatible formats.

This whole process can be performed with greater or lesser depth and definition and will provide the key results and the public to where we should direct. This section will discuss later so supposed to differentiate the product created if it is for an expert or simply informative public and what that entails.

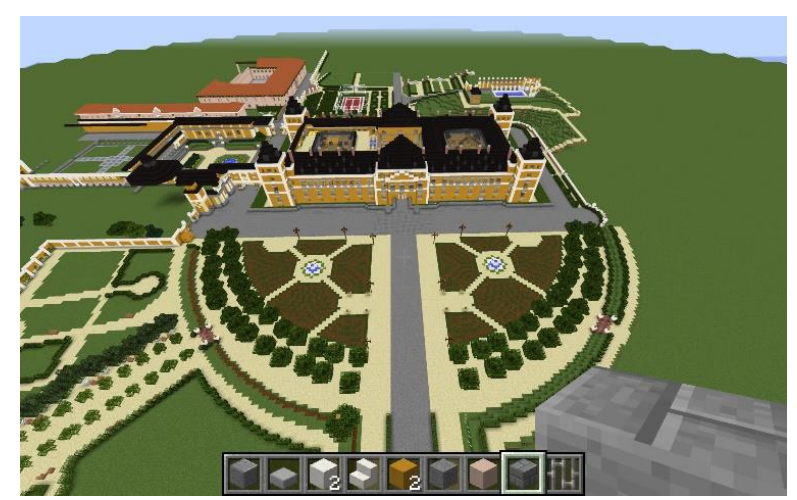

Figure 3. El Pardo. 3D recreation.

Once the 3D object we anchored in the concrete actual location, this is what is known as "positioning" and for it on the market three types of systems:

- Recognition: This is the most advanced technology to the integration of 3D objects. Iconic uses objects found in the real environment as markers to introduce virtual elements. Its use is very sensitive to changes in lighting or certain perspectives, but can be applied easily without considering the geo viewer. - Markers. It uses a series of similar to BIDI or QR codes in space and to recognize the pen tablet puts the 3D object in the right place geometric markings; code from the three coordinate axes are generated to guide the object. The only requirement is that the resolution of the camera allows the identification of these markers and difficulties lie in the location of codes in different parts of the building and in the correct alignment of the definitions of the object facing the reality that surrounds it. Yet more development is used to date for use on easy.

- Georeferencing: Use the GPS coordinates to locate the position of the 3D object. Eliminates the need for any marker to generate the coordinate axis, but the margin of error in generating the image from the point of view of the viewer is much higher.
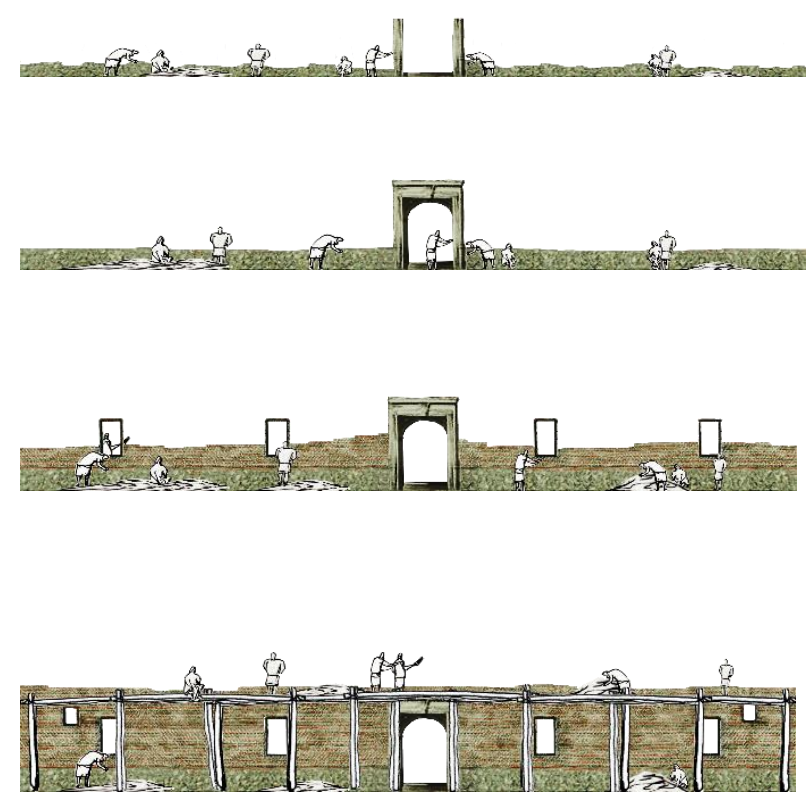

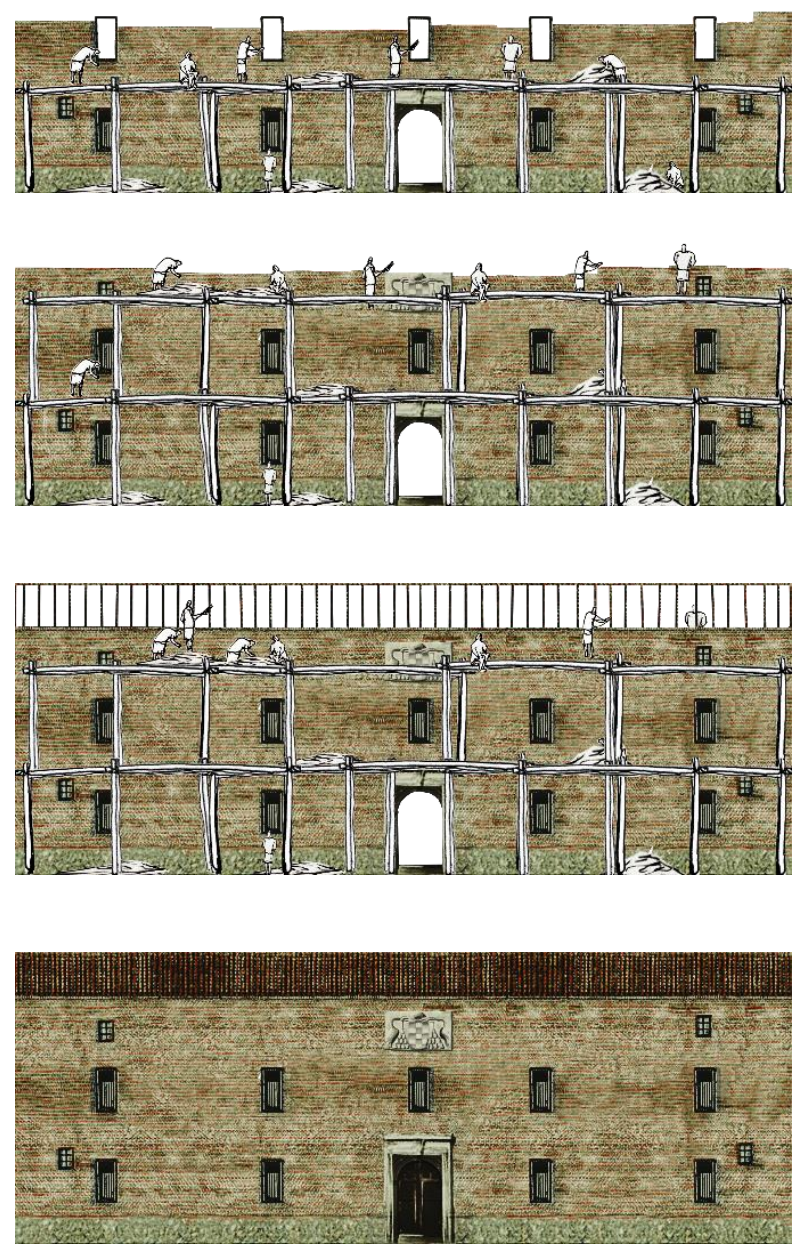

Figure 4. AR Drawings. Process of construction of the façade University of Alcalá.

Finally, we need a viewer through which an image of the real environment with integrated virtual elements. In this case, we must take into account the size of the device and the screen resolution or the ability to geo instruments available to it. To date, they have developed various types of devices to display Augmented Reality:

- Viewers: static screens are large offering an overview through a fixed and allow replace $3 \mathrm{D}$ image camera.

- PDA: They are smaller portable viewers that store 3D images and synchronized with the place in which it is located.

- HMD ("Head Mounted Display") This is glasses for viewing $3 \mathrm{D}$ images, so perfectly synchronized with the movements of the subject leads.

- "Smartphones" or tablets: These are generic devices through specific Internet applications, as well as carrying the camera built for viewing Augmented Reality.

As stated Redondo Dominguez, the successful development of the "Augmented Reality" it has occurred when it has been possible to apply from mobile phones last generation, equipped with cameras of high quality and processing power and connectivity (2012: 10). Therefore the current standard for this technology are applications for "smartphones" that run through recognition of markers in the real world.

\section{THE FUTURE OF AUGMENTED REALITY IN ARCHITECTURE.}

Once recognized the technology developed, we face the same analysis from a critical point of view, assessing their suitability to the discipline that concerns us is the architecture and within archeology. Augmented Reality is developing at breakneck speed in various branches of knowledge as in video games, tourism and even in medicine, which is used for testing operations or to allow the surgeon to superimpose visual data and see the delimitation of clean edges one, invisible to the eye, thereby facilitating procedures tumor.

In the field of architecture and archeology RA development it is now closely linked to archaeological recreations linked to tourism and real estate development and the results are beginning to be really interesting quality and recreation. While it would have to take a step beyond its possible use in creative fields and constructive for what greater precision and technicality necessary phases. For now, the difficulties are emerging in this new technology are several although evolution is very fast and at the time this article is published has been able to advance a few more steps and new problems have appeared.

One of the major difficulties is when developing projects Augmented Reality is that visual elements must be coordinated perfectly with real objects, since a small error of orientation can cause noticeable misalignment between virtual objects and physical that you remove all likelihood to experience. Another of the difficulties the RA with the incorporation in architecture is the ability recreation with architectural quality. As well as other specialties acceptable iconic or near the object represented as in traffic or surgery, archaeological recreations quality "render" and lightings have to be more realistic images are, as we have already used to that level of definition in our jobs and everything that is not equal will lead to implausible and rejectable recreations in this professional environment. In this case the lighting models and matching lighting environment is key to successful integration. Keep in mind that the possibility of changing the point of view that gives us the RA, also requires illumination change of location taking into account changes in the days, seasons and hours of the day. These and other difficulties lead us to continue to research in this field from a critical point of view and to invest in it, both economic resources and people.

In the field of architecture its current developments incident from a point of view of promotion ahead of a sale of the product to the customer, where still some images are undeveloped for more professional requirements so in that aspect should influence the lines of future development. But then without abandoning this line, we should develop technical tools such as in-depth analysis of constructions, visualization tools different constructive solutions in creative processes but also restoration and maintenance. This line of work would allow us to use the RA almost like an X-ray or thermal imaging camera that allows us, from where the database building, visualize the inside of the walls where the structures and facilities are located, and to act in time and actual location.

Despite the widespread applications of Augmented for "smartphones" Reality, there is still much to improve the integration of $3 \mathrm{D}$ objects in the real world. Everything indicates that Augmented Reality is one more link in development initiatives in architecture and is therefore likely to be overtaken by new technologies that improve the ability to recover the past, so an exciting world where development 
opens new technologies, but always in the hands of a critical analysis to ensure its suitability for architecture and archeology with the minimum standards required by our scientific community.

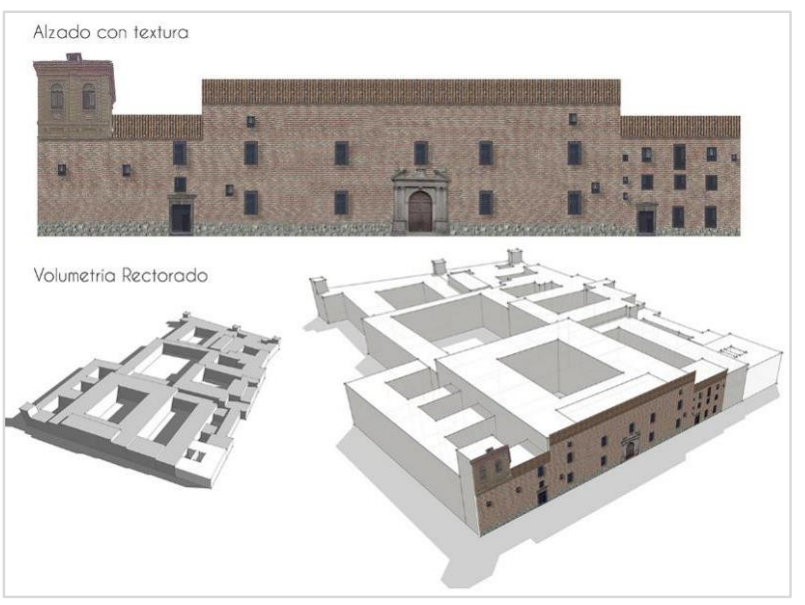

Figure 5. AR Drawings. Elevations and volumetry. Façade Alcalá de Henares

\section{RESULTS}

This line of research has already given the following results in projects and awards:

- 2nd Prize 2016-Campus of International Excellence "Intelligent Energy" Rey Juan Carlos University / University of Alcalá With the project "Connect Smart Cities and their heritage through augmented reality".

- "Augmented Reality to learn to narrate the historical heritage" 2016

- "The image as a teaching tool in the university" 2015

- "Augmented Reality applied to the overlapping of temporal strata in the documentation, management and conservation of architectural heritage. Case study: The real Spanish sites. El Pardo. 2014

- "Augmented Reality: Learning Meetings between Audiovisual Communication and Architecture" 2014

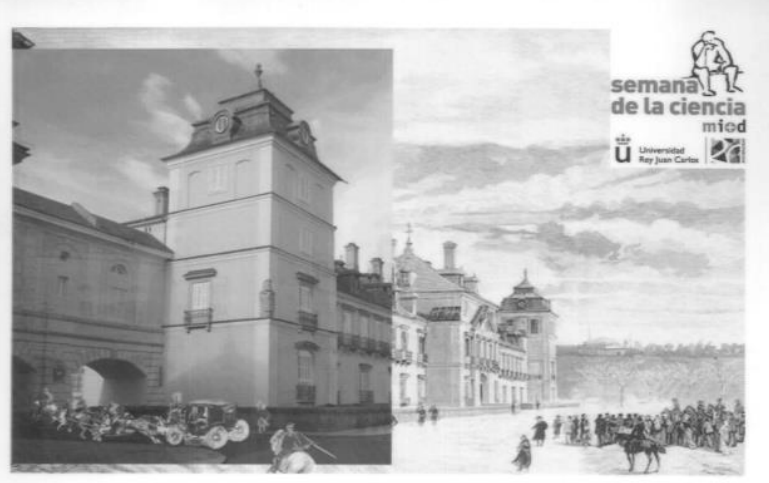

Figure 6. AR Drawings. El Pardo.

\section{BIBLIOGRAPHY}

Alonso, N., et al. 2001. Análisis de escenarios de futuro en realidad aumentada. Aplicación al yacimiento arqueológico de Els Vilars. In: Actas del $2^{o}$ Congreso Internacional de Interacción Persona-Ordenador (Interacción'2001), Salamanca. pp. 16-18.

Blasco Senabre, J. et al. 2011. Procesos de documentación arqueológica y generación de modelos virtuales. Virtual Archaeology Review. 3, pp. 65-70.

Fernández Álvarez, Á. J. 2010. De las arquitecturas virtuales a la realidad aumentada: un nuevo paradigma de visualización arquitectónica”. In: Actas del X Congreso Internacional de Expresión Gráfica aplicada a la Edificación. https://web.ua.es/es/x-apega-2010/documentos/id-118.pdf (20 Jan. 2017)

Flores Gutiérrez, M. 2011. Visor de Realidad Aumentada en Museos (RAM) para Exposiciones Situadas en Entornos Cerrados. Virtual Archaeology Review. 3, pp. 87-91.

Gil, T. and Santacana, J. 2013. De lo real a lo digital: la arqueología reconstructiva y la obtención de imágenes virtuales para la investigación en la didáctica del patrimonio. HER\&MES, 13, pp. 16-35.

Gómez Robles, L. and Quirosa García, V. 2009. Nuevas tecnologías para difundir el Patrimonio Cultural: las reconstrucciones virtuales en España. Revista Electrónica de Patrimonio Histórico.

9
http://revistaseug.ugr.es/index.php/erph/article/view/3357/33 69.

Gutiérrez, D.; Hernández, L.A. 2003. Potencial de la realidad virtual en el ámbito del Patrimonio. http://videalab.udc.es/files/stuff/pdf/rv2003_patrimonio.pdf

Iñarra, S.; Juan, F.; Llinares, M.C. 2013. Arquitecturas irreales y perspectiva emocional. EGA. Revista de Expresión Gráfica Arquitectónica. 18(21), pp. 204-215.

Milgram, P. and Kishino, F. 1994. A taxonomy of mixed reality visual displays. IEICE Transactions on Information Systems, $\quad$ E77

https://cs.gmu.edu/ zduric/cs499/Readings/r76JBo-

(12), Milgram_IEICE_1994.pdf.

Redondo, E. 2012. La ciudad como aula digital. Enseñando urbanismo y arquitectura mediante mobile learning y la realidad aumentada. ACE: Arquitectura, Ciudad y Entorno. 19 , pp. $27-54$

Ruiz Torres, D. 2011. Realidad Aumentada, Educación y Museos. Icono 14. 2, pp. 212-226 